\title{
A NEW STAGE ON THE LANDFILLS OF ESTONIA: LEAKAGE WATER INVESTIGATIONS AND MANAGEMENT
}

\author{
Riho Karjus \\ ENTEC Ltd, Tallinn, ESTONIA
}

\section{KEYWORDS}

landfill conditions, leakage water, investigations

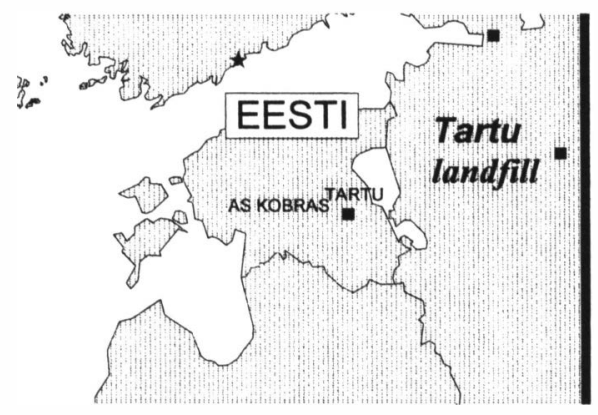

\section{PREFACE}

At the moment there is registered over 500 landfills with different sizes in the Estonian Landfill Catalogue. According to Estonian legislation and National Environmental Action Plan the number of landfills should be reduced and the present situation updated.

There are only few new small ( $<5 \mathrm{ha}$ ) landfills in Estonia which are built in accordance with environmental requirements.

In South-Estonia the biggest - Tartu landfill is under reconstruction. The landfill is located 5 $\mathrm{km}$ from town of Tartu and it serves app. 200000 inhabitants of South-Estonia. Since 1971 that place is used for landfilling purposes. Total area of the landfill is 28.3 ha. Wastes cover around 10.6 ha of the area with estimated volume ca $500000 \mathrm{~m}^{3}$. 
Since 1996 environment research company KOBRAS LTD has carried out several environmental impact studies of the landfill. The results of the studies are showing that significant water pollution occurs on the landfill area. In order to reduce water pollution on the landfill area of town of Tartu reconstruction works of the landfill were started last year. Up to now the area covered with wastes is reduced. At the same time leakage water and stormwater collection systems and biological treatment for wastewater are built.

Should be emphasised that these kinds of works are first such cases in Estonia.

\section{INVESTIGATIONS AND METHODOLOGY}

\section{Sampling}

Within the project in 1996 the groundwater and surface water quality was monitored respectively in five wells and one weir. Groundwater samples for comparison were taken app. $200 \mathrm{~m}$ in the SW direction from landfill.

6 surface water samples were taken from border channel for analysing $\mathrm{pH}, \mathrm{BOD}_{7}, \mathrm{NH}_{4}, \mathrm{NO}_{2}$, $\mathrm{NO}_{3}, \mathrm{P}_{\text {tot }}, \mathrm{Cl}, \mathrm{SO}_{4}$ and conductivity (CTY). Concentration of oil products and phenols was measured twice. Sampling took place during the period from April to November.

In the most characteristic places $2 \times 2$ samples from additional weirs were taken. Concentration of $\mathrm{pH}, \mathrm{NH}_{4}, \mathrm{NO}_{2}, \mathrm{NO}_{3}, \mathrm{Cl}, \mathrm{SO}_{4}$ and conductivity was found.

From five wells $5 \times 6$ samples were taken. Concentration of $\mathrm{pH}, \mathrm{COD} \mathrm{Cr}, \mathrm{NH}_{4}, \mathrm{NO}_{2}, \mathrm{NO}_{3}$, $\mathrm{P}_{\text {tot }}, \mathrm{Cl}, \mathrm{SO}_{4}$ and conductivity was found. Concentration of oil products and phenols was measured twice. Sampling took place during the period from June to November. Also water table was measured.

The leakage water was sampled twice in 6 weirs. Concentration of $\mathrm{pH}, \mathrm{COD} \mathrm{Cr}, \mathrm{NH}_{4}, \mathrm{NO}_{2}$, $\mathrm{NO}_{3}, \mathrm{P}_{\text {tot }}, \mathrm{Cl}, \mathrm{SO}_{4}$, oil products, conductivity, phenols, $\mathrm{As}, \mathrm{Ba}, \mathrm{Cd}, \mathrm{Hg}, \mathrm{Pb}$ was found. The first sampling took place in May and the second in November. In April 2 samples for $\mathrm{pH}$, $\mathrm{NH}_{4}, \mathrm{NO}_{2}, \mathrm{NO}_{3}$, Ptot, $\mathrm{Cl}, \mathrm{SO}_{4}$, conductivity were taken and analysed. 6 samples were taken from soil to analyse oil products. 4 samples were taken from manure spill and concentration of $\mathrm{pH}, \mathrm{BOD}_{5}, \mathrm{COD} \mathrm{Cr}, \mathrm{NH}_{4}, \mathrm{~N}_{\text {tot }}$ and $\mathrm{P}_{\text {tot }}$ was found.

\section{Comparison weirs}

Samples from drainage system collector of Aardla polder were taken for water quality and pollution intensity comparison with monitoring wells. Aardla polder is located ca $200 \mathrm{~m}$ to $\mathrm{SW}$ from the landfill. Collector is located in similar hydrogeological conditions like landfill does.

In addition data from two other wells for comparison was used: Saare well with unpolluted and Raadi well with polluted groundwater.

\section{Geological situation}

Tartu landfill is located on Aardla polder, which is built on the Konsu-Reola primeval valley. Polder is surrounded by highway in the north and east, and by Konsu channel in the south and west. In the central part of the polder small lake is situated.

The landfill is located on the service area (watershed) of II pumping station which means that water runoff from the landfill area is not by gravity flow. 
Data available showing geological situation of the Konsu-Reola primeval valley is insufficient and therefore near the landfill 3 additional boreholes in depth $9.5 \mathrm{~m}$ to $16.5 \mathrm{~m}$ were drilled. The geological situation of the landfill can be described as follows: in depth 1.5-2.7 m peat; in depth 3.0-7.0 m various grain-sized sands, mainly fine and extrafine sand, also micro layers of gravel and gravel with sand and loam were found in the depth. Below sand varved clay occurs. In depth $9.0 \mathrm{~m}$ the Devonian sandstone occurs.

\section{Leakage water}

At the time of investigations there are no leakage water collection and treatment facilities on the Aardlapalu landfill yet.

Table 1. Chemical concentrations of leakage water

\begin{tabular}{|c|c|c|c|c|c|}
\hline & & \multicolumn{3}{|c|}{ Leakage 6 weirs 14 samples } & \multirow{2}{*}{\begin{tabular}{|l|}
$\begin{array}{l}\text { Uppersoilwa } \\
\text { ter }\end{array}$ \\
Mean \\
\end{tabular}} \\
\hline & & Mean & Max & Min & \\
\hline $\mathrm{pH}$ & & 8.4 & 9.1 & 7.6 & 7.03 \\
\hline Conductivity & $\mu \mathrm{S} / \mathrm{cm}$ & 8414 & 19800 & 2310 & 7149 \\
\hline $\mathrm{COD} \mathrm{Cr}$ & $\mathrm{mgO} / \mathrm{l}$ & 1371 & 4300 & 460 & 404 \\
\hline $\mathrm{NH}_{4}$ & $\mathrm{mgN} / \mathrm{l}$ & 214 & 650 & 20 & 51 \\
\hline $\mathrm{NO}_{2}$ & $\mathrm{mgN} / \mathrm{l}$ & 1.6 & 8.0 & 0.001 & 0.001 \\
\hline $\mathrm{NO}_{3}$ & $\mathrm{mgN} / \mathrm{l}$ & 35 & 150 & 0.04 & 0.44 \\
\hline $\mathrm{P}_{\text {tot }}$ & $\mathrm{mg} / \mathrm{l}$ & 3.1 & 7.0 & 0.6 & 1.5 \\
\hline $\mathrm{Cl}$ & $\mathrm{mg} / \mathrm{l}$ & 1502 & 3340 & 220 & 655 \\
\hline $\mathrm{SO}_{4}$ & $\mathrm{mg} / \mathrm{l}$ & 220 & 750 & 50 & 136 \\
\hline Oil products & $\mathrm{mg} / \mathrm{l}$ & 0.22 & 1.0 & 0.05 & \\
\hline Light phenols & $\mathrm{mg} / \mathrm{l}$ & 0.42 & 3.2 & 0.03 & \\
\hline As & $\mathrm{mg} / \mathrm{l}$ & 0.01 & 0.032 & 0.002 & \\
\hline $\mathrm{Ba}$ & $\mathrm{mg} / \mathrm{l}$ & 0.34 & 0.60 & 0.02 & \\
\hline $\mathrm{Pb}$ & $\mathrm{mg} / \mathrm{l}$ & 0.04 & 0.23 & & \\
\hline $\mathrm{Cd}$ & $\mathrm{mg} / \mathrm{l}$ & $<0.002$ & & & \\
\hline $\mathrm{Hg}$ & $\mathrm{mg} / \mathrm{l}$ & $<0.0001$ & & & \\
\hline
\end{tabular}

Annually estimated water input to the landfill is $16155 \mathrm{~m}^{3}$. Water incoming with waste and manure as well as evaporation/precipitation ratio is taken into account. Territorial changes in chemical compoundments of filtrates are significant which can be explained with various age of the dump.

Changes in chemical concentrations in time and in different places occur.

\section{SURFACE WATER}


At the time of investigations collector channels or ditches did not surround the landfill. In the neighbourhood are several polder drainage ditches. By such ditches was driven away also landfill leakage water.

Water level in the ditches is depending on pumping frequency. Also there are beavers dams on the ditches and these are regulating water outflow from the landfill area.

\section{Outflow}

Hereby values of several parameters in the outflow from the landfill via polder drainage ditch are given.

Mean annual value of conductivity in the outflow was $1032 \mu \mathrm{S} / \mathrm{cm}$.

In comparison weir in the river with nature condition was the value $552 \mu \mathrm{S} / \mathrm{cm}$.

Mean annual value of $\mathrm{pH}$ in the outflow was 7.4. In the river it was respectively 7.95.

Alkalinity values were 14.8 and $13.8 \mathrm{mg}$-ekv/l.

Mean $\mathrm{BOD}_{7}$ values were $6.4 \mathrm{mgO} / \mathrm{l}$ and $1.5 \mathrm{mgO} / \mathrm{l}$ respectively

During the last decade concentration of $\mathrm{BOD}_{7}$ was increasing but in comparison weir it was decreasing.

Mean value of $\mathrm{NH}_{4}$ in the outflow and in the river has significantly increased during the monitored period since 1982 (Table 2).

Mean value of $\mathrm{NO}_{2}$ in the outflow was $0.02 \mathrm{mgN} / \mathrm{l}$

$0.95 \mathrm{mgN} / \mathrm{l}$ and in comparison weir it was $0.96 \mathrm{mgN} / \mathrm{l}$. In the outflow significant fluctuations in $\mathrm{NO}_{3}$ values during the years was found. At the same time there was no fluctuations of $\mathrm{NO}_{3}$ values in the river.

Mean value of $P_{\text {tot }}$ was in the outflow $0.12 \mathrm{mg} / \mathrm{l}$ and maximum value was $0.17 \mathrm{mg} / \mathrm{l}$. There has been increase in the values

Mean concentration of $\mathrm{Cl}^{-}$in the outflow was $75 \mathrm{mg} / \mathrm{l}$ and in the river it was $9.41 \mathrm{mg} / \mathrm{l}$. In the outflow slight increase during the monitoring period occurred.

Course of $\mathrm{SO}_{4}$ values is similar to $\mathrm{Cl}^{-}$values and mean values are $80 \mathrm{mg} / \mathrm{l}$ and $18 \mathrm{mg} / \mathrm{l}$ respectively.

In the samples oil products were not found.

\section{ESTIMATED WATERQUALITY IN OUTFLOW}

During the investigation period since 1982 water quality of the landfill outflow continuously has worsened indicated especially in $\mathrm{BOD}_{7}, \mathrm{NH}_{4}, \mathrm{P}_{\text {tot }}, \mathrm{Cl}, \mathrm{SO}_{4}$ content. Values of the characteristics have been much higher than in comparison weir in the river.

It is necessary as soon as possible to treat leakage water of the landfill.

Table 2. Mean values of the characteristics of surface water in outflow of the landfill (L) and in the river $(\mathrm{R})$.

\begin{tabular}{|r|c|c|c|c|c|c|c}
\hline Year & $\begin{array}{c}\text { Number of } \\
\text { samples }\end{array}$ & $\mathrm{pH}$ & $\mathrm{BOD}_{7}$ & $\mathrm{NH}_{4}$ & $\mathrm{NO}_{3}$ & $\mathrm{Cl}$ & $\mathrm{SO}_{4}$ \\
\hline $1982 \mathrm{~L}$ & 5 & 7.5 & 2.8 & 0.75 & 0.18 & 12 & 48 \\
$\mathrm{R}$ & 9 & 7.94 & 2.3 & 0.161 & 1.30 & 12.56 & 22.67 \\
\hline $1983 \mathrm{~L}$ & 10 & 7.7 & 2.9 & 1.98 & 0.45 & 23 & 59 \\
$\mathrm{R}$ & 12 & 8.11 & 2.3 & 0.268 & 0.87 & 14.67 & 21.42 \\
\hline
\end{tabular}




\begin{tabular}{|r|c|c|c|c|c|c|c|}
\hline $1984 \mathrm{~L}$ & 12 & 7.7 & 3.1 & 2.08 & 0.17 & 37 & 79 \\
$\mathrm{R}$ & 12 & 8.02 & 2.1 & 0.196 & 0.88 & 15.74 & 21.58 \\
\hline $1985 \mathrm{~L}$ & 4 & 7.2 & 5.4 & 2.78 & 0.24 & 39 & 92 \\
$\mathrm{R}$ & 4 & 7.66 & 3.9 & 0.188 & 1.11 & 17.25 & 16.25 \\
\hline $1993 \mathrm{~L}$ & 4 & 7.6 & 5.2 & 0.79 & 2.84 & 27 & 135 \\
$\mathrm{R}$ & 12 & 7.95 & 2.0 & 0.108 & 1.05 & 10.10 & 19.95 \\
\hline $1996 \mathrm{~L}$ & 8 & 7.4 & 6.4 & 6.96 & 0.95 & 75 & 80 \\
$\mathrm{R}$ & 11 & 7.95 & 1.5 & 0.067 & 0.86 & 9.41 & 17.91 \\
\hline
\end{tabular}

\section{Groundwater}

Table 3. Saare (unpolluted) and Raadi (polluted) well.

\begin{tabular}{|c|c|c|c|c|c|c|c|c|c|c|c|}
\hline Well & Date & $\mathrm{NH} 4$ & $\mathrm{NO} 3$ & $\mathrm{Ptot}$ & $\mathrm{Cl}$ & $\mathrm{SO} 4$ & $\mathrm{Ca}$ & $\mathrm{Mg}$ & $\mathrm{Na}$ & $\mathrm{K}$ & $\mathrm{CTY}$ \\
\hline & & $\mathrm{mgN} / \mathrm{l}$ & $\mathrm{mgN} / \mathrm{l}$ & $\mathrm{mg} / \mathrm{l}$ & $\mathrm{mg} / \mathrm{l}$ & $\mathrm{mg} / \mathrm{l}$ & $\mathrm{mg} / \mathrm{l}$ & $\mathrm{mg} / \mathrm{l}$ & $\mathrm{mg} / \mathrm{l}$ & $\mathrm{mg} / \mathrm{l}$ & $\mu \mathrm{S} / \mathrm{cm}$ \\
\hline Saare & 26.09 & 0.05 & $<0.15$ & 0.18 & 2.7 & 8.4 & 25.6 & 8.3 & 10 & 1.6 & 218 \\
\hline Raadi & 29.09 & 0.68 & 35 & 0.022 & 210 & 70 & 149 & 51.5 & 150 & 20 & 1810 \\
\hline
\end{tabular}

Table 4. Mean characteristics of the landfill groundwater

\begin{tabular}{|c|c|c|c|c|c|c|c|}
\hline \multirow[t]{2}{*}{ Characteristics } & & \multicolumn{6}{|c|}{ Sampling place } \\
\hline & & Well 1 & Well 2 & Well 3 & Well 4 & Well 5 & Collector \\
\hline \multirow[t]{3}{*}{$\mathrm{pH}$} & Mean & 7.18 & 7.39 & 7.14 & 7.11 & 7.05 & 7.41 \\
\hline & Max. & 7.48 & 7.72 & 7.42 & 7.24 & 7.37 & 8.23 \\
\hline & Min. & 7.01 & 7.13 & 6.92 & 6.96 & 6.91 & 7.1 \\
\hline \multirow[t]{3}{*}{ Conductivity } & Mean & 1864 & 997 & 977 & 1061 & 7149 & 686 \\
\hline & Max. & 2090 & 1060 & 1180 & 1220 & 7830 & 721 \\
\hline & Min. & 1670 & 939 & 846 & 906 & 6300 & 645 \\
\hline \multirow{3}{*}{$\begin{array}{l}\mathrm{COD} \mathrm{Cr} \text {, } \\
\mathrm{mgO} / 1\end{array}$} & Mean & 242 & 202 & 232 & 235 & 500 & 31 \\
\hline & Max. & 400 & 420 & 520 & 440 & 640 & 70 \\
\hline & Min. & 90 & 13 & 22 & 100 & 360 & 7 \\
\hline \multirow{3}{*}{$\begin{array}{l}\mathrm{NH} 4, \\
\mathrm{mgN} / \mathrm{l}\end{array}$} & Mean & 45.43 & 0.66 & 4.58 & 3.84 & 50.95 & 0.02 \\
\hline & Max. & 64 & 1.4 & 22 & 5.9 & 300 & 0.057 \\
\hline & Min. & 26 & 0.26 & 0.45 & 2.3 & 0.03 & 0.005 \\
\hline \multirow{3}{*}{$\begin{array}{l}\mathrm{NO} 2, \\
\mathrm{mgN} / 1\end{array}$} & Mean & 0.04 & 0.01 & 0.05 & 0.02 & 0.003 & 0.002 \\
\hline & Max. & 0.12 & 0.02 & 0.09 & 0.04 & 0.013 & 0.003 \\
\hline & Min. & 0.002 & 0.003 & 0.022 & 0.001 & 0.001 & 0.001 \\
\hline \multirow{3}{*}{$\begin{array}{l}\mathrm{NO} 3, \\
\mathrm{mgN} / 1\end{array}$} & Mean & 0.4 & 0.2 & 3.0 & 0.3 & 0.4 & 7.5 \\
\hline & \begin{tabular}{|l} 
Max. \\
\end{tabular} & 1.6 & 0.7 & 6.0 & 1.1 & 1.3 & 20.0 \\
\hline & Min. & 0.03 & 0.04 & 0.23 & 0.04 & 0.04 & 4.2 \\
\hline \multirow{3}{*}{$\begin{array}{l}\text { Ptot, } \\
\mathrm{mg} / \mathrm{l}\end{array}$} & Mean & 0.31 & 0.13 & 0.25 & 0.15 & 1.46 & 0.05 \\
\hline & Max. & 0.49 & 0.25 & 0.55 & 0.28 & 1.80 & 0.08 \\
\hline & Min & 0.15 & 0.03 & 0.09 & 0.03 & 1.20 & 0.02 \\
\hline \multirow{3}{*}{$\begin{array}{l}\mathrm{Cl}, \\
\mathrm{mg} / \mathrm{l}\end{array}$} & Mean & 100 & 39 & 47 & 52 & 656 & 40 \\
\hline & Max & 130 & 64 & 64 & 110 & 750 & 50 \\
\hline & Min. & 70 & 22 & 36 & 28 & 510 & 28 \\
\hline \multirow{3}{*}{$\begin{array}{l}\mathrm{SO} 4, \\
\mathrm{mg} / \mathrm{l}\end{array}$} & Mean & 254 & 229 & 117 & 112 & 136 & 68 \\
\hline & Max. & 320 & 310 & 160 & 190 & 180 & 90 \\
\hline & Min. & 180 & 170 & 62 & 40 & 90 & 42 \\
\hline $\mathrm{Ca}^{2}$ & Mean & 141 & 165 & 129 & 167 & 175 & 105 \\
\hline
\end{tabular}




\begin{tabular}{|l|l|l|l|l|l|l|l|}
\cline { 2 - 9 } $\mathrm{mg} / \mathrm{l}$ & & & & & & & \\
\hline $\begin{array}{l}\mathrm{Mg}^{2}, \\
\mathrm{mg} / \mathrm{l}\end{array}$ & Mean & 71 & 41 & 45 & 48 & 197 & 29 \\
\hline $\begin{array}{l}\mathrm{Na}, \\
\mathrm{mg} / \mathrm{l}\end{array}$ & Mean & 82.5 & 6.75 & 14 & 19.5 & 500 & 6.5 \\
\hline $\begin{array}{l}\mathrm{K}, \\
\mathrm{mg} / \mathrm{l}\end{array}$ & Mean & 55 & 4.65 & 3.8 & 4.35 & 360 & 1.7 \\
\hline
\end{tabular}

\section{SUMMARY}

\section{Leakage water}

There are no facilities to collect and to treat leakage waters on the Aardlapalu landfill. Problem should be solved according to relevant requirements as soon as possible.

\section{Surface water}

Quality of surface water worsened during the period $1982 \ldots 1996$. There are direct inflows of heavily polluted leakage water into surface water bodies (ditches, channels).

\section{Groundwater}

The landfill area is polluted especially by $\mathrm{As}, \mathrm{Ba}, \mathrm{Pb}$, oil products, and phenols. Outside the dump area no pollution coming from landfill was found. 